\title{
ANALISIS USAHATANI KACANG PANJANG (Vigna sinensis L.) VARIETAS PARADE
}

(Studi Kasus di Kelurahan Pataruman Kecamatan Pataruman Kota Banjar)

\author{
Oleh: \\ Alek Hermawan $^{1}$, Dini Rochdiani ${ }^{2}$, Tito Hardiyanto ${ }^{3}$ \\ 1) Mahasiswa Fakultas Pertanian Universitas Galuh \\ 2) Dosen Fakultas Pertanian Universitas Galuh \\ 3) Dosen Fakultas Pertanian Universitas Galuh
}

\begin{abstract}
Abstrak
Penelitian ini bertujuan untuk mengetahui : 1) Besarnya biaya, penerimaan dan pendapatan dari usahatani kacang panjang (Vigna sinensis L.) per hektar per satu musim tanam di Kelurahan Pataruman Kecamatan Pataruman Kota Banjar, dan 2) Besarnya $R / C$ usahatani kacang panjang (Vigna sinensis L.) per hektar per satu musim tanam di Kelurahan Pataruman Kecamatan Pataruman Kota Banjar. Jenis penelitian yang digunakan dalam penelitian ini adalah studi kasus pada petani Kacang Panjang (Vigna sinensis L.) di Kelurahan Pataruman Kecamatan Pataruman Kota Banjar. Pengambilan sampel ditentukan dengan total sampling, dan analisis data menggunakan analisis biaya, penerimaan, pendapatan dan R/C. Hasil penelitian menunjukkan bahwa : 1) Besarnya biaya yang dikeluarkan dari usahatani kacang panjang varietas parade per hektar dalam satu musim tanam di Kelurahan Pataruman Kecamatan Pataruman Kota Banjar rata-rata Rp 13.335.455,32. Penerimaan rata-rata $R p$ 24.057.471,26 per hektar dalam satu musim tanam, sehingga pendapatan rata-rata $R p$ 10.722.015,94 per hektar dalam satu musim tanam. 2)Berdasarkan analisis imbangan Penerimaan dan Biaya $(R / C)$ pada usahatani kacang panjang varietas parade di Kelurahan Pataruman Kecamatan Pataruman Kota Banjar adalah rata-rata sebesar 1,80 artinya apabila biaya yang dikeluarkan sebesar $R p$ 1,00 maka diperoleh penerimaan sebesar Rp 1,80 dan pendapatan sebesar $R p$ 0,80. Maka usahatani kacang panjang varietas parade di Kelurahan Pataruman Kecamatan Pataruman Kota Banjar layak untuk diusahakan.
\end{abstract}

\section{Kata kunci : analisis usahatani, kacang panjang varietas parade}

\section{PENDAHULUAN}

Menurut Cahyono (2005) bahwa, kacang panjang (Vigna sinensis L.) merupakan salah satu jenis sayur kacang-kacangan. Kacang panjang memiliki nilai komersil tinggi dan mempunyai peran yang sangat besar dalam memenuhi kebutuhan pangan gizi masyarakat, terutama terhadap kebutuhan protein nabati. Peningkatan produksi kacang-kacangan masih harus ditingkatkan, karena komoditi ini banyak dikonsumsi oleh seluruh lapisan masyarakat. Faktor iklim dan tanah sangat berpengaruh terhadap pertumbuhan dan perkembangan tanaman kacang panjang. Tanaman ini dapat tumbuh dan berproduksi dengan baik menghendaki sifat fisik tanah yang genbur, kedalaman tanah cukup dalam dan tanah yang mudah mengikat air. Karena tanah yang gembur akan meningkatkan perkembangan perakaran, sehingga penyerapan hara berlangsung dengan baik yang berdampak bagi peningkatan pertumbuhan secara keseluruhan. Tanah yang gembur memiliki drainase yang baik. Jenis tanah yang cocok adalah regosol, andosol dan latosol yang merupakan tanah lempung ringan atau liat berpasir dengan tekstur tanah pasir sampai lempung berdebu. Jenis tanah ini pula memiliki daya ikat dan drainase yang baik.

Pertumbuhan yang baik bagi komoditi ini juga didukung oleh pendapat Nazarudin dalam Chuzaimah (2013), yang menuliskan bahwa tanaman kacang panjang (Vigna sinensis L.) dapat tumbuh baik dan berproduksi tinggi pada suhu optimal 25 derajat celcius. Namun tanaman tersebut masih toleran dan berproduksi dengan baik pada suhu udara maksimal sampai 32 derajat celcius dan suhu minimal 18 derajat celcius. Di luar kisaran suhu di atas tanaman kacang panjang pertumbuhannya menjadi terhambat dan produksinya rendah.

Badan Pusat Statistik (2014), menjelaskan bahwa daerah penyebaran yang menjadi sentra 
produsen kacang panjang sebagian besar di Pulau Jawa. Secara umum penanaman kacang panjang yang dilakukan petani merupakan tanaman monokultur sehingga rata-rata hasil yang didapatkan dari tanaman ini relatif masih rendah. Keberhasilan usahatani kacang panjang (Vigna sinensis L.) tidak terlepas dari kegiatan budidaya, yang dimulai dari pemilihan bibit unggul, pengolahan tanah, pemeliharaan, pemanenan dan penanganan pasca panen, dan pemasaran.

Kota Banjar merupakan salah satu kota di Jawa Barat yang beberapa tahun terakhir mulai membudidayakan kacang panjang khususnya varietas parade. Luas dan produksi kacang panjang (Vigna sinensis L.) terbesar berada di Kecamatan Pataruman dengan luas 15,59 hektar, produksi mencapai 1.480,34 kwintal, dan produktivitas mencapai 94,95 kwintal per hektar.

Kelurahan Pataruman dengan luas panen 8,79 hektar, dengan jumlah produksi sebesar 845,77 kwintal, dan produktivitas mencapai 96,22 kwintal per hektar. Sedangkan Kelurahan Sukamukti merupakan kelurahan yang paling sedikit hasil produksi kacang panjang (Vigna sinensis L.) yakni luas panen sebesar 0,60 hektar dengan jumlah produksi mencapai 56,23 kwintal.

Budidaya kacang panjang (Vigna sinensis L.) memiliki prospek ekonomi yang baik. Pasar kacang panjang (Vigna sinensis L.) yang telah jelas dan permintaan pasar yang selalu tinggi memudahkan para pembudidaya memasarkan hasil produksi kacang panjang. Kacang panjang (Vigna sinensis L.) merupakan salah satu produk komersial dan dapat dikembangkan dengan teknik yang sederhana. Di samping itu, potensi pasar kacang panjang (Vigna sinensis L.) masih sangat terbuka dan memiliki nilai ekonomis. Sebab, bisa dikonsumsi semua kalangan (Suriawiria, 2006).

Jenis kacang panjang yang diusahakan para petani di Kelurahan Pataruman Kecamatan Pataruman Kota Banjar adalah varietas parade. Hal ini dikarenakan varietas kacang panjang parade memiliki keunggulan yaitu harga lebih tinggi dari pada varietas lain, ukuran lebih panjang dan tidak mudah layu.

Meskipun para petani telah terbiasa mengusahakan tersebut, tetapi para petani tidak mengetahui secara pasti berapa besarnya biaya, penerimaan, dan pendapatan dari usahatani kacang panjang (Vigna sinensis L.) yang diusahakannya. Oleh karena itu perlu dilakukan analisis usahatani kacang panjang (Vigna sinensis L.) tersebut, sehingga dapat diketahui apakah usahatani kacang panjang (Vigna sinensis L.) tersebut menguntungkan atau tidak.

Berdasarkan uraian tersebut, maka penelitian ini dilaksanakan dengan tujuan untuk mengetahui : 1) Besarnya biaya, penerimaan dan pendapatan dari usahatani kacang panjang (Vigna sinensis L.) varietas parade per hektar per satu musim tanam di Kelurahan Pataruman Kecamatan Pataruman Kota Banjar. 2) Besarnya R/C usahatani kacang panjang (Vigna sinensis L.) varietas parade per hektar per satu musim tanam di Kelurahan Pataruman Kecamatan Pataruman Kota Banjar.

\section{METODE PENELITIAN \\ Jenis Penelitian}

Metode yang digunakan dalam penelitian ini adalah studi kasus pada petani kacang panjang (Vigna sinensis L.) varietas parade di Kelurahan Pataruman Kecamatan Pataruman Kota Banjar. Menurut Iskandar (2009) studi kasus bertujuan untuk mengembangkan metode kerja paling efisien, maknanya peneliti mengadakan telaah secara mendalam, kesimpulan hanya berlaku atau terbatas pada kasus tertentu saja.

\section{Operasionalisasi Variabel}

1. Petani kacang panjang (Vigna sinensis L.) varietas parade adalah petani yang mengusahakan tanaman kacang panjang (Vigna sinensis L.) varietas parade sebagai mata pencaharian.

2. Usahatani kacang panjang (Vigna sinensis L.) varietas parade adalah suatu usaha yang dilakukan di atas sebidang lahan diusahakan tanaman kacang panjang ((Vigna sinensis L.) varietas parade sebagai tanaman utama.

3. Lahan adalah sebidang tanah yang dimiliki oleh petani untuk kegiatan usahatani kacang panjang (Vigna sinensis L.) varietas parade yang diukur dalam satuan hektar (ha).

4. Biaya produksi adalah seluruh biaya yang dikeluarkan oleh petani selama proses produksi masih berlangsung yang dinyatakan dalam rupiah per satu musim tanam $(\mathrm{Rp} / \mathrm{per}$ satu musim tanam), yang terdiri dari :

a. Biaya tetap adalah biaya yang besar kecilnya tidak dipengaruhi oleh besar kecilnya produksi yang terdiri dari :

1) Pajak bumi dan bangunan yang digunakan dalam mengusahakan kacang panjang (Vigna sinensis L.) varietas parade yang dinyatakan dalam satuan rupiah per satu musim tanam (Rp/satu musim tanam). 
2) Penyusutan alat, dihitung per satu musim tanam dan diniai dalam satuan rupiah (Rp/ satu musim tanam), besarnya penyusutan alat dihitung dengan menggunakan metode garis lurus (Straight line method) yang digunakan menurut Suratiyah (2006) dengan rumus sebagai berikut :

1. Penyusutan $=$

Nilai Pembelian-Nilai Sisa

Umur ekonomis alat yang digunakan

2. Nilai sisa merupakan nilai pada waktu alat itu sudah tidak dapat digunakan lagi, dan dianggap nol.

3) Bunga modal tetap dihitung dalam satuan persen berdasarkan bunga bank yang berlaku pada saat penelitian dan dihitung dalam satuan rupiah per satu musim tanam (Rp/satu musim tanam).

b. Biaya variabel adalah biaya yang besar kecilnya pengaruhi oleh besar kecilnya produksi yang meliputi :

1) Upah tenaga kerja, yaitu tenaga kerja yang dicurahkan untuk usahatani kacang panjang, baik tenaga kerja keluarga maupun tenaga kerja di luar keluarga dihitung dalam Hari Orang Kerja (HOK) dihitung dalam satuan rupiah per satu musim tanam (Rp/ per satu musim tanam).

2) Biaya sarana produksi :

- Benih kacang panjang yang digunakan dihitung dalam satuan kilogram dan dinilai dalam satuan rupiah per satu musim tanam (Rp/satu musim tanam).

- Jumlah pupuk yang digunakan dihitung dalam satuan kilogram $(\mathrm{Kg})$, dan dinilai dalam satuan rupiah per musim tanam ( $\mathrm{Rp} /$ satu musim tanam).

- Jumlah pestisida yang digunakan dihitung dalam satuan liter (lt) dan dinilai dalam satuan rupiah per musim tanam (Rp/ satu musim tanam).

- Jumlah mulsa perak plastik hitam yang digunakan dihitung dalam satuan rol, dan dinilai dalam satuan rupiah per musim tanam (Rp/satu musim tanam).

- Jumlah tali rapia yang digunakan dihitung dalam satuan gulung, dan dinilai dalam satuan rupiah per musim tanam (Rp/satu musim tanam).

- Jumlah ajir yang digunakan dihitung per batang, dan dinilai dalam satuan rupiah per musim tanam (Rp/satu musim tanam).

- Bunga modal variabel dihitung berdasarkan bunga bank yang berlaku saat penelitian, dinyatakan satuan rupiah per musim tanam (Rp/satu musim tanam).

5. Penerimaan adalah total produksi yang dihasilkan dikali dengan harga kacang panjang (Vigna sinensis) yang dihitung dalam satuan rupiah (Rp).

6. Pendapatan yaitu penerimaan dikurangi biaya produksi yang dinilai dalam satuan rupiah (Rp).

7. $\mathrm{R} / \mathrm{C}$ merupakan perbandingan antara penerimaan total dengan biaya total.

8. Satu kali proses produksi adalah satu proses yang dimulai dari persiapan lahan sampai dengan pemanenan selama 5 bulan.

\section{Teknik Pengumpulan Data}

Jenis data yang digunakan meliputi data primer dan data sekunder. Data primer diperoleh dengan observasi, wawancara, serta pengisian kuesioner oleh responden. Data sekunder adalah data yang sudah dikumpulkan oleh pihak lain. Diperoleh melalui studi kepustakaan dan studi literatur.

\section{Teknik Penarikan Sampel}

Pada penelitian ini pengambilan sampel ditentukan dengan total sampling. Menurut Sugiyono (2008), total sampling adalah teknik penentuan sampel bila semua anggota populasi digunakan sebagai sampel. Dalam penelitian ini yang menjadi sampel yaitu semua anggota petani kacang panjang (Vigna sinensis L.) varietas parade diambil secara sensus sebanyak 30 orang di Kelurahan Pataruman Kecamatan Pataruman Kota Banjar. Pengertian dari sensus menurut Sugiyono (2008), adalah teknik penentuan sampel bila semua anggota populasi digunakan sebagai sampel. 


\section{Rancangan Analisis Data}

1. Biaya total usahatani kacang panjang (Vigna sinensis $\mathrm{L}$.) varietas parade dihitung dengan rumus menurut Soekartawi (2002) sebagai berikut:

$$
\mathrm{TC}=\mathrm{TFC}+\mathrm{TVC}
$$

Dimana :

$$
\begin{aligned}
& \text { TC }=\text { Total Cost } \text { (Biaya total) } \\
& \text { TFC }=\text { Total Fixed Cost (Biaya Tetap) } \\
& \text { T'VC = Total Variable Cost (Biaya } \\
& \text { Variabel) }
\end{aligned}
$$

2. Analisis penerimaan dihitung dengan rumus menurut Suratiyah (2006) sebagai berikut:

$$
\begin{array}{ll} 
& \mathbf{R}=\mathbf{P y} \cdot \mathbf{Y} \\
\text { Dimana: } & \\
\mathrm{R} & =\text { Revenue }(\text { Penerimaan) } \\
\mathrm{Py} & =\text { Price }(\text { Harga Produksi) }(\mathrm{Rp} / \mathrm{kg}) \\
\mathrm{Y} & =\text { Yield }(\text { Jumlah Produksi) }(\mathrm{kg})
\end{array}
$$

3. Analisis pendapatan, menurut Suratiyah (2006) dapat dinyatakan dengan rumus:

$$
\boldsymbol{\pi}=\mathbf{R}-\mathbf{T C}
$$

Dimana :

$$
\begin{array}{ll}
\pi & =\text { Pendapatan } \\
\mathrm{R} & =\text { Revenue }(\text { Penerimaan }) \\
\mathrm{TC} & =\text { Total Cost }(\text { Biaya Total) }
\end{array}
$$

4. Untuk mengetahui kelayakan usahatani kacang panjang (Vigna sinensis L.) varietas parade dapat digunakan analisis imbangan penerimaan dengan biaya, menurut Suratiyah (2006) dapat menggunakan rumus sebagai berikut :

$$
\mathrm{R} / \mathrm{C}=\frac{\text { Penerimaan total }}{\text { Biaya total }}
$$

Dengan ketentuan sebagai berikut :

- Apabila R/C > 1, maka usaha tersebut menguntungkan.

- Apabila R/C = 1, maka usaha tersebut tidak untung dan tidak rugi.

- Apabila R/C $<1$, maka usaha tersebut merugikan.

\section{Tempat dan Waktu Penelitian}

Penelitian ini dilaksanakan di Kelurahan Pataruman Kecamatan Pataruman Kota Banjar. Penelitian ini mulai bulan Juni 2014 sampai selesai dengan melalui empat tahapan sebagai berikut :

1. Tahapan persiapan, yaitu survey awal, penyusunan Usulan Penelitian dan Seminar Usulan Penelitian dilaksanakan pada Juni 2013.

2. Tahap penelitian dilaksanakan pada Juli 2013.
3. Tahap pengolahan dan analisis data dilaksanakan pada Juli 2014

4. Tahap penulisan hasil penelitian dilaksanakan pada Juli 2014 sampai dengan selesai.

\section{HASIL PENELITIAN DAN PEMBAHASAN Identitas Responden}

Gambaran tentang responden yang mengusahakan kacang panjang varietas parade di Kelurahan Pataruman dapat diidentifikasikan dari 30 petani sebagai responden, karakteristik umum dari responden adalah sebagai berikut:

1. Umur Responden

Umur responden bervariasi, dari yang termuda berumur 25 tahun sampai yang tertua 66 tahun. Umur petani di Kelurahan Pataruman sebagian besar termasuk angkatan kerja produktif karena responden yang berumur 15 sampai 64 tahun sebanyak 93,33 persen merupakan angkatan kerja produktif, hal ini berarti termasuk golongan umur produktif sehingga secara ekonomis mempunyai potensi untuk berproduksi dan merupakan angkatan kerja. Dengan semua petani berada dalam kelompok usia produktif, memungkinkan daerah tersebut dapat berkembang. Hal ini disebabkan petani pada umumnya lebih mudah menerima informasi dan inovasi baru serta lebih cepat mengambil keputusan dalam penerapan teknologi baru yang berhubungan dengan usahanya. Dengan kondisi usia tersebut juga diharapkan petani mampu membaca pasar dan memanfaatkan peluang untuk meningkatkan penerimaan usahanya.

2. Pendidikan Responden

Sebagian besar responden berpendidikan rendah karena sebanyak 80 persen hanya tamatan Sekolah Dasar, Sekolah Lanjutan Tingkat Pertama 16,37 persen dan 3,33 persen tamatan Sekolah Lanjutan Tingkat Atas.

3. Jumlah Tanggungan Keluarga Responden Tanggungan keluarga petani merupakan banyaknya orang yang secara ekonomis masih menjadi tanggungan petani yang bersangkutan. Sebagian besar petani mempunyai tanggungan sebanyak 3 orang yaitu sebesar 30 persen, dan terkecil mempunyai tanggungan keluarga sebanyak 5 orang atau sebesar 3,33 persen. Tanggungan keluarga ini dapat menjadi beban bagi petani 
sehingga modal usahanya dipakai untuk konsumsi atau kebutuhan hidup sehari-hari.

4. Kepemilikan Luas Lahan

Berdasarkan data luas penguasaan lahan petani padi di wilayah Kelurahan Pataruman termasuk dalam skala sempit karena luas lahan yang dimiliki petani kurang dari 1 hektar.

\section{Analisis Biaya, Penerimaan, Pendapatan, dan R/C Usahatani Kencur}

Biaya yang diperhitungkan adalah semua biaya yang dikeluarkan selama proses produksi, meliputi biaya tetap dan biaya variabel. Biaya tetap adalah jenis biaya yang tidak mengalami perubahan dengan bertambah atau berkurangnya produksi, meliputi : Pajak Bumi dan Bangunan, Penyusutan Alat dan Bunga Modal Tetap. Untuk lebih jelasnya mengenai biaya tetap dapat dilihat pada Tabel 1.

Tabel 1. Rata-rata Biaya Tetap Usahatani Kacang Panjang Varietas Parade

\begin{tabular}{|l|l|c|c|}
\hline No & \multicolumn{1}{|c|}{$\begin{array}{c}\text { Jenis Biaya } \\
\text { Tetap }\end{array}$} & $\begin{array}{c}\text { Besarnya } \\
(\mathbf{R p} / \text { Ha/Musim })\end{array}$ & $\begin{array}{c}\text { Persentase } \\
(\mathbf{\%})\end{array}$ \\
\hline 1. & $\begin{array}{l}\text { Pajak Bumi dan } \\
\text { Bangunan }\end{array}$ & $29.704,14$ & 12,72 \\
\hline 2. & Penyusutan Alat & $196.408,05$ & 84,13 \\
\hline 3. & $\begin{array}{l}\text { Bunga Modal } \\
\text { Tetap }\end{array}$ & $7.348,65$ & 3,15 \\
\hline \multicolumn{2}{|c|}{$\begin{array}{l}\text { Jumlah Biaya Tetap } \\
\text { Total }\end{array}$} & $\mathbf{2 3 3 . 4 6 0 , 8 3}$ & $\mathbf{1 0 0 , 0 0}$ \\
\hline \multicolumn{2}{|c|}{} \\
\hline
\end{tabular}

Berdasarkan Tabel 1 rata-rata biaya tetap per hektar pada usahatani kacang panjang varietas parade meliputi nilai Pajak Bumi dan Bangunan Rp 29.704,14 (12,72\%), Penyusutan Alat Rp 196.408,05 (84,13\%), dan Bunga Modal Tetap Rp 7.348,65 (3,15\%) sehingga jumlah keseluruhan biaya tetap rata-rata adalah $\mathrm{Rp}$ $67.933,14$, dan rata-rata biaya total tetap per hektar Rp 233.460,83.

Biaya variabel adalah jenis biaya yang besar kecilnya dipengaruhi oleh naik turunnya produksi atau tergantung pada skala produksi, meliputi biaya produksi, tenaga kerja, dan bunga modal variabel. Untuk lebih jelasnya mengenai biaya variabel dapat dilihat pada Tabel 2 .
Tabel 2. Rata-rata Biaya Variabel Usahatani Kacang Panjang Varietas Parade

\begin{tabular}{|c|l|c|c|}
\hline No & $\begin{array}{c}\text { Jenis Biaya } \\
\text { Variabel }\end{array}$ & $\begin{array}{c}\text { Besarnya } \\
(\mathbf{R p / H a / M u s i m )})\end{array}$ & $\begin{array}{c}\text { Persentase } \\
(\mathbf{\%}))\end{array}$ \\
\hline 1 & Benih & $576.436,78$ & 4,40 \\
\hline 2 & Pupuk & $762.094,54$ & 5,82 \\
\hline 3 & Pestisida & $615.103,45$ & 4,69 \\
\hline 4 & Tenaga Kerja & $6.534 .482,76$ & 49,87 \\
\hline 5 & Mulsa & $1.515 .517,24$ & 11,57 \\
\hline 6 & Ajir & $2.652 .155,17$ & 20,24 \\
\hline 7 & Tali Rafia & $33.793,10$ & 0,26 \\
\hline 8 & $\begin{array}{l}\text { Bunga Modal } \\
\text { Variabel }\end{array}$ & $412.411,45$ & 3,15 \\
\hline & Jumlah & $\mathbf{1 3 . 1 0 1 . 9 9 4 , 4 9}$ & $\mathbf{1 0 0 , 0 0}$ \\
\hline
\end{tabular}

Berdasarkan Tabel 2 rata-rata biaya variabel usahatani kacang panjang varietas parade per hektar per musim meliputi benih Rp 576.436,78 (4,40\%), pupuk Rp 762.094,54 (5,82\%), pestisida Rp 615.103,45 (4,69), tenaga kerja Rp 6.534.482,76 (49,87\%), mulsa Rp 1.515.517,24 (11,57\%), ajir Rp 2.652.155,17 (\%), tali rafia Rp $33.793,10(0,26 \%)$, dan bunga modal variabel $\mathrm{Rp}$ $412.411,45(3,5 \%)$, sehingga rata-rata total biaya variabel per satu hektar per musim adalah $\mathrm{Rp}$ 13.101.994,49.

Jadi, rata-rata biaya total usahatani kacang panjang varietas parade meliputi biaya tetap dan biaya variabel total, yaitu Biaya Tetap Total sebesar Rp Rp 233.460,83 dan Biaya Variabel Total Rp 13.101.994,49, maka jumlahnya adalah Rp 13.335.455,32.

Penerimaan adalah rata-rata produksi usahatani kacang panjang per musim dikalikan dengan harga jual. Rata-rata produksi usahatani kacang panjang varietas parade yang dicapai oleh responden 9.622,99 kilogram per hektar per satu musim tanam. Adapun harga jual kacang panjang varietas parade berkisar rata-rata $\mathrm{Rp} 2.500,00$ per kilogram. Maka penerimaan rata-rata Rp 24.057.471,26 per hektar per musim tanam.

Pendapatan merupakan selisih antara penerimaan dengan biaya total. Penerimaan usahatani merupakan perkalian antara produk yang dihasilkan dengan harga jual produk. Pada usahatani kacang panjang penerimaan rata-rata Rp 24.057.471,26 per hektar per musim tanam, dan biaya total Rp 13.335.455,32 per musim tanam. Sehingga pendapatan rata-rata $\mathrm{Rp}$ 10.722.015,94 per hektar per musim tanam.

Suratiyah (2006) menyatakan bahwa semakin tinggi ratio penerimaan yang diterima petani, maka usahanya tersebut semakin menguntungkan. Pada usahatani kacang panjang, $\mathrm{R} / \mathrm{C}$ sebagai berikut : penerimaan $\mathrm{Rp}$ 24.057.471,26 per hektar per musim tanam dan 
biaya total $\mathrm{Rp} 13.335 .455,32$ per hektar per musim tanam maka diperoleh $\mathrm{R} / \mathrm{C}$ sebesar 1,80.

$\mathrm{R} / \mathrm{C}$ sebesar 1,80 artinya bahwa setiap satu rupiah biaya yang dikeluarkan petani akan memperoleh penerimaan sebesar 1,80 rupiah dan pendapatan sebesar 0,80 rupiah.

\section{KESIMPULAN DAN SARAN \\ Kesimpulan}

Berdasarkan hasil penelitian dan pembahasan, maka dapat ditarik kesimpulan sebagai berikut :

1. Besarnya biaya yang dikeluarkan dari usahatani kacang panjang varietas parade per hektar dalam satu musim tanam di Kelurahan Pataruman Kecamatan Pataruman Kota Banjar rata-rata $\mathrm{Rp} 13.335 .455,32$. Penerimaan rata-rata $\mathrm{Rp} 24.057 .471,26$ per hektar dalam satu musim tanam, sehingga pendapatan rata-rata $\mathrm{Rp} 10.722 .015,94$ per hektar dalam satu musim tanam.

2. Berdasarkan analisis imbangan Penerimaan dan Biaya (R/C) pada usahatani kacang panjang varietas parade di Kelurahan Pataruman Kecamatan Pataruman Kota Banjar adalah rata-rata sebesar 1,80 artinya apabila biaya yang dikeluarkan sebesar $\mathrm{Rp}$ 1,00 maka diperoleh penerimaan sebesar $\mathrm{Rp}$ 1,80 dan pendapatan sebesar Rp 0,80. Maka usahatani kacang panjang varietas parade di Kelurahan Pataruman Kecamatan Pataruman Kota Banjar layak untuk diusahakan.

\section{Saran}

Berdasarkan hasil pembahasan dan kesimpulan maka disarankan : Para petani kacang panjang varietas parade di Kelurahan Pataruman Kecamatan Pataruman untuk lebih meningkatkan produktivitas dan pendapatannya, perlu adanya bantuan modal dari lembaga keuangan yang tidak memerlukan prosedur yang menyulitkan petani dan modal tersebut harus disesuaikan besarnya dengan kebutuhan petani sehingga usahataninya dapat berjalan secara efektif dan efesien.

\section{DAFTAR PUSTAKA}

Abdulkarim, A. 2006. Pendidikan Kewarganegaraan. Bandung: Grafindo.

Agrina. 2010. Prospek Usaha Budidaya Kacang Panjang. Agromedia. Jakarta.

Arikunto, S. 2006. Prosedur Penelitian Suatu Pendekatan Praktek. Rieneka Cipta. Jakarta.

Badan Pusat Statistik Pusat. 2014. Statistik Indonesia, Jakarta.
Badan Pusat Statistik Jawa Barat. 2014. Jawa Barat dalam Angka 2013. Bandung.

Badan Pusat Statistik Kota Banjar. 2014. Kota Banjar dalam Angka 2013. Banjar.

Cahyono, B. 2005. Kacang Panjang Teknik Budidaya dan Analisis Usahataninya. CV. Aneka Ilmu. Semarang.

Chuzaimah, 2013. Analisis Ekonomi Komoditi Kacang Panjang di Kabupaten Banyuasin Sumatera Selatan. Jurnal Ilmiah Agriba Nomor 2 Edisi September Tahun 2013.

Iskandar, 2009. Metodologi Penelitian Kualitatif. Gaung Persada Perss. Jakarta.

Kelurahan Pataruman, 2013. Profil Kelurahan Pataruman. Banjar.

Rahardi. F. 2009. Agribisnis Tanaman Perkebunan. Penebar Swadaya. Jakarta.

Rahayu, E., 2007. Budidaya Kacang Panjang. Jakarta: Penebar Swadaya.

Rahim, A. 2008. Pengantar, Teori, dan Kasus Ekonomika Pertanian. Cetakan Kedua. Jakarta: Penebar Swadaya.

Riduwan. 2004. Metode Riset. Rineka Cipta. Jakarta.

Samadi, B. 2007. Usahatani Kacang Panjang. Kanisus. Yogyakarta.

Santika, A. 2008. Agribisnis Cabai. Penebar Swadaya. Jakarta.

Soekartawi, 2005. Analisa Usahatani. PT. Raja Grafindo Persada. Jakarta.

Sugiyono, 2008. Metode Penelitian Bisnis. Alfabeta. Bandung

Suharto, E. 2009. Membangun Masyarakat Memberdayakan Rakyat Kajian Strategis Pembangunan Kesejahteraan Sosial. Rafika Aditama. Bandung.

Sukendar, 2014. Kacang Varietas Parade. (shukendar.blogspot.com. diakses 24 Juni 2014).

Suratiyah, K. 2006. Ilmu Usahatani. Penebar Swadaya. Jakarta.

Tukan, C.J.M. 2004. Pemasaran Pertanian. Agrivita. Jakarta.

Widyananto, C.S., 2010. Analisis Efisiensi Penggunaan Faktor-Faktor Produksi Pada Usahatani Bawang Putih. Skripsi. Fakultas Ekonomi UNDIP. Semarang. 